\title{
DESIGN OF CIRCULAR SLOTTED RECTANGULAR MICROSTRIP PATCH ANTENNA WITH DUAL-RESONANCE FOR WLAN/WIMAX APPLICATIONS
}

\author{
Sena Esen BAYER KESKIN ${ }^{1 *}$, Cem GÜLER ${ }^{1}$
}

${ }^{1}$ Kırklareli University, Faculty of Engineering, Electrical and Electronics Engineering Dept., Kırklareli, Turkey

\begin{tabular}{|c|c|}
\hline Keywords & Abstract \\
\hline $\begin{array}{l}\text { Microstrip Patch Antenna, } \\
\text { Wideband, } \\
\text { Dual Resonance, } \\
\text { WLAN, } \\
\text { Circular Slotted. }\end{array}$ & $\begin{array}{l}\text { In this work, a design for enhancing bandwidth of a dual-resonant circular slotted } \\
\text { patch antenna for } 2.4-3.5 \mathrm{GHz} \text { WLAN/WiMAX applications is proposed and tested. } \\
\text { The designed antenna is a modified form of the rectangular patch antenna consisting } \\
\text { of three identical circular slots in antenna surface and it printed on an FR- } 4 \\
\text { substrate. This antenna has two different operating frequencies, with center } \\
\text { frequencies of } 2.592 \text { and } 3.338 \mathrm{GHz} \text {. Classical microstrip antennas yield a maximum } \\
\text { bandwidth of about } 8 \% \text {. By incorporating slots in antenna, the bandwidth of the } \\
\text { antenna is improved. The fractional bandwidth at } 2.592 \mathrm{GHz} \text { is } 50.9 \% \text { and at } 3.358 \\
\mathrm{GHz} \text { is } 39.5 \% \text {. The proposed antenna is simulated, fabricated and tested. Measured } \\
\text { results showed good agreement with the simulated results. The gain of the antenna } \\
\text { is } 2.169 \mathrm{~dB} \text { at } 2.59 \mathrm{GHz} \text { and } 2.175 \mathrm{~dB} \text { at } 3.338 \mathrm{GHz} \text {. }\end{array}$ \\
\hline
\end{tabular}

\section{WLAN UYGULAMALARI İÇİN ÇİFT REZONANS FREKANSINDA ÇALIŞAN DAİRESEL YARIKLI DİKDÖRTGENSEL MİKROŞERİT YAMA ANTEN TASARIMI}

\author{
Anahtar Kelimeler \\ Mikroșerit Yama Anten, \\ Genişbant, \\ Çift Rezonans, \\ WLAN, \\ Dairesel Yarık.
} \begin{abstract}
Öz
Bu çalışmada, 2,4-3,5 GHz WLAN/WiMAX uygulamalarında bant genişliği arttırımı için çift rezonanslı dairesel yarıklı yama anten önerilmiş ve analiz edilmiştir. Tasarlanan anten, dikdörtgensel yama antenin yüzeyinden 3 tane dairesel yarık oluşturulması ile elde edilmiş ve anten FR-4 malzemesi kullanılarak ürettirilmiştir. Bu anten, merkez frekansları 2,592 GHz ve 3,338 GHz olmak üzere iki farklı çalıșma frekansına sahiptir. Klasik mikroşerit antenlerin maksimum oransal bant genişliği \%8 civarındadır. Klasik mikroşerit antene dairesel yarıkların açılması ile oransal bant genişliği 2,592 GHz merkez frekansında \%50,9 arttırılmış olup, 3,338 GHz merkez frekansında ise \%39,5 arttırılmıștır. Antenin kazancı 2,592 GHz'de 2,169 dB ve 3,338 GHz'de 2,175 dB olarak bulunmuştur. Önerilen antenin simülasyonu, üretimi ve analizleri yapılmıştır. Ölçüm sonuçlarının simülasyon sonuçları ile tutarlı olduğu gözlenmiştir.
\end{abstract}

Alıntı / Cite

Bayer Keskin, S. E., Güler, C., (2021). Design of Circular Slotted Rectangular Microstrip Patch Antenna with DualResonance for WLAN/WiMAX Applications, Journal of Engineering Sciences and Design, 9(4), 1296-1301. \begin{tabular}{l|l}
\hline Yazar Kimliği / Author ID (ORCID Number) & Makale Süreci / Article Process
\end{tabular}

S. E. Bayer Keskin, 0000-0001-8309-3393

C. Güler, 0000-0002-6631-7559

Başvuru Tarihi / Submission Date 17.01 .2020

Revizyon Tarihi / Revision Date

Kabul Tarihi / Accepted Date

Yayım Tarihi / Published Date

17.01 .2020
15.09 .2021

22.09 .2021

20.12.2021

\section{Introduction}

In recent years, it has become indispensable for mobile applications and wireless communication to operate multiple features at the same time. There is increasing demand for antennas having broa dBand and multiple resonance frequencies in recent years. The design of lightweight, low cost, high bandwidth microstrip antennas is essential for wireless devices to be able to transmit images, speech and data in various frequency bands at the

\footnotetext{
*ilgili yazar / Corresponding author: senakeskin@klu.edu.tr, +90-288-214-05-14
} 
same time. The patch antenna idea appeared to be proposed by Deschamps in the early 1950s. A few years later, a microstrip antenna patent was issued by Gutton and Baissinot. In the 1970s, thin, surface-compatible microstrip antennas were produced for military applications such as missiles and space shuttles. Microstrip antennas have many advantages such as being small in size, easy adaptation to electronic circuits, low power consumption, high performance, low cost, mechanical durability and dual frequency applications. Because of these advantages, they have become a widely used antenna type in almost all areas of wireless communication. However, microstrip antennas have disadvantages of narrow bandwidth and low efficiency as a result of various losses. Much of the development work in microstrip antennas has trying to overcome these problems, in order to satisfy systems requirements.

\section{Literature Review}

Data transmission in various frequency bands of wireless devices is achieved by using a multi-band or broa dBand antenna. Broa dBand and multiple resonance frequencies in microstrip patch antennas have recently been in increasing demand.

There are many studies in the literature covering the WLAN applications of microstrip patch antennas (Armağan vd., 2016; Yu vd., 2012; gemio vd., 2009). Yassin et. al. (2013) examined dual band rectangular microstrip patch antenna operating at $2.4 \mathrm{GHz}$ and $3.5 \mathrm{GHz}$ frequency. Return loss is $-22 \mathrm{~dB}$ and $-27 \mathrm{~dB}$, bandwidths are $65 \mathrm{MHz}$ and $50 \mathrm{MHz}$ at $2.4 \mathrm{GHz}$ and $3.5 \mathrm{GHz}$, respectively. Wu et. al. (2013) presented a C and T-shaped patch and a dual-band patch antenna consisting of a $50 \mathrm{ohm}$ microstrip line feeding these patches for wireless communication systems. The antenna is operating between $2.5 \mathrm{GHz}$ and $3.5 \mathrm{GHz}$ frequency. $-10 \mathrm{~dB}$ impedance bandwidth is $200 \mathrm{MHz}$ at 2.5 $\mathrm{GHz}(2.50 \mathrm{GHz}-2.70 \mathrm{GHz})$ and $800 \mathrm{MHz}$ at $3.5 \mathrm{GHz}$. Designed antenna is suitable for using Multi Input Multi Output (MIMO) systems. Rosaline et. al. (2015) suggested a microstrip antenna design with complementary split ring resonators (CSRR) developed from hexagonal microstrip patch antenna. The antenna operates at GSM $1.8 \mathrm{GHz}$ and WLAN $3.5 \mathrm{GHz}$ frequency bands. Antenna gain is $0.62 \mathrm{dBi}$ and $1.07 \mathrm{dBi}$ at $1.8 \mathrm{GHz}$ and $3.5 \mathrm{GHz}$, respectively. Kumari et. al (2012) have designed a triangular two-element dielectric resonator antenna (DRA) array for wireless local area network (WLAN) and microwave access (WiMAX) applications. Impedabce bandwidth of the suggested antenna is $2.16-2.94 \mathrm{GHz}$ for 2.4 GHz WLAN applications and 3.22-3.63 GHz for 3.5 GHz WiMAX applications. Liu et. al (2016) presented a new design with linear polarization for the single-feed double-layer dual-band patch antenna. The antenna has E-shaped and U-shaped patches of $42 \mathrm{~mm}$ and $31 \mathrm{~mm}$. Suggested antenna impedance bandwidths are $26.9 \%$ and $7.1 \%$, respectively. Gupta et. al. (2015) suggested meander slot microstrip patch antenna for dual-band applications at $2400 \mathrm{MHz}$ and $3500 \mathrm{MHz}$. Suggested antenna bandwidths are $177.4 \mathrm{MHz}$ and $146.6 \mathrm{MHz}$ and gains are $2.44 \mathrm{~dB}$ and $3.35 \mathrm{~dB}$ at $2400 \mathrm{MHz}$ and $3500 \mathrm{MHz}$, respectively. It is observed that the slits on the patch and partial ground planes increased the bandwidth and gain on the microstrip patch antennas. (Değirmenci vd.,2014; İsmail vd., 2015; Sharma vd., 2012).

In this paper, a circular slotted microstrip patch antenna with dual-resonance is proposed and designed for. Wireless Local Area Network (WLAN, 2.4-3.5 GHz) applications as well as Worldwide interoperability for Microwave Access (WiMAX -IEEE 802.16e). The frequency range of the designed antenna is between $2.26 \mathrm{GHz}$ and $3.58 \mathrm{GHz}(1.32 \mathrm{GHz})$ and has a dual resonance frequency of $2.592 \mathrm{GHz}$ and $3.338 \mathrm{GHz}$. Fractal Bandwidths are $50.9 \%$ at $2.592 \mathrm{GHz}$ and $39.5 \%$ at $3.338 \mathrm{GHz}$ resonance frequency. The proposed antenna designed and simulated using CST Microwave Studio. Numerical analysis results such as resonance frequency, bandwidth, directional gain, radiation efficiency and surface current distributions are included. Table 1 shows the comparison of the performance of similar antennas with the antenna proposed in this study. It is observed that the proposed antenna enhances the bandwidth.

Table 1. Comparison between different antenna designs.

\begin{tabular}{|c|c|c|c|}
\hline Study & $\begin{array}{c}\text { Dimension } \\
\left(\mathbf{m m}^{\mathbf{3}} \mathbf{)}\right.\end{array}$ & $\begin{array}{c}\text { Operation } \\
\text { Frequency }\end{array}$ & $\begin{array}{c}\text { Bandwidth } \\
\mathbf{( < - 1 0 ~ d B )}\end{array}$ \\
\hline $\begin{array}{c}\text { (Yassin et. al., } \\
\text { 2013) }\end{array}$ & $4.6 \times 36 \times 1.6$ & $\begin{array}{c}2.4 \mathrm{GHz} \text { and } 3.5 \\
\mathrm{GHz}\end{array}$ & $\begin{array}{c}65 \mathrm{MHz} \text { and } \\
50 \mathrm{MHz}\end{array}$ \\
\hline (Wu et.al., 2013) & $95 \times 60 \times 0.8$ & $\begin{array}{c}2.5 \mathrm{GHz} \text { and } 3.66 \\
\mathrm{GHz}\end{array}$ & $\begin{array}{c}200 \mathrm{MHz} \text { and } \\
800 \mathrm{MHz}\end{array}$ \\
\hline $\begin{array}{c}\text { (Gupta et.al., } \\
\text { 2015) }\end{array}$ & $37.75 \times 31.75 \times 1.5$ & $\begin{array}{c}2.4 \mathrm{GHz} \text { and } 3.5 \\
\mathrm{GHz}\end{array}$ & $\begin{array}{c}177.4 \mathrm{MHz} \text { and } 146.6 \\
\mathrm{MHz}\end{array}$ \\
\hline $\begin{array}{c}\text { (Kumari et.al., } \\
\text { 2012) }\end{array}$ & $60 \times 56 \times 1.6$ & $\begin{array}{c}2.4 \mathrm{GHz} \text { and } 3.5 \\
\mathrm{GHz}\end{array}$ & $\begin{array}{c}780 \mathrm{MHz} \text { and } \\
410 \mathrm{MHz}\end{array}$ \\
\hline $\begin{array}{c}\text { (Liu et.al., 2016) } \\
\text { Proposed } \\
\text { Antenna }\end{array}$ & $60 \times 45 \times 1.5$ & $\begin{array}{c}2.4 \mathrm{GHz} \text { and } 3.5 \\
\mathrm{GHz}\end{array}$ & $\begin{array}{c}700 \mathrm{MHz} \text { and } \\
260 \mathrm{MHz}\end{array}$ \\
\hline
\end{tabular}




\section{Material and Method}

Microstrip patch antennas are formed by placing the radiating plane on the substrate in the desired geometry. The patch and ground plane generally have uniform geometries, but non-uniform geometries are also used. The substrate used in the proposed antenna is a FR-4 material having a thickness of $1.6 \mathrm{~mm}$, dielectric permeability of 4.3 and loss tangent of $\tan \delta=0.019 \cong 0.02$. The patch is excited via $50 \Omega$ microstrip transmission line. Designed dual-resonance microstrip patch antenna has partial ground structure and circular slots on the rectangular patch to improve the bandwidth. Figure 1 shows the geometry of the proposed antenna. Here, $L_{d}$ is substrate length, $W_{d}$ is substrate width and also ground width, $L_{p}$ is patch length, $W_{p}$ is patch width, $L_{f}$ is feed line length, $W_{f}$ is feed line width, $C_{1}=C_{3}, C_{2}=C_{4}, C_{5}$ and $C_{6}$ are angular length of circular slots, $L_{g}$ is ground length, $a$ is gap width of inset feed and $x$ is gap length of inset feed.
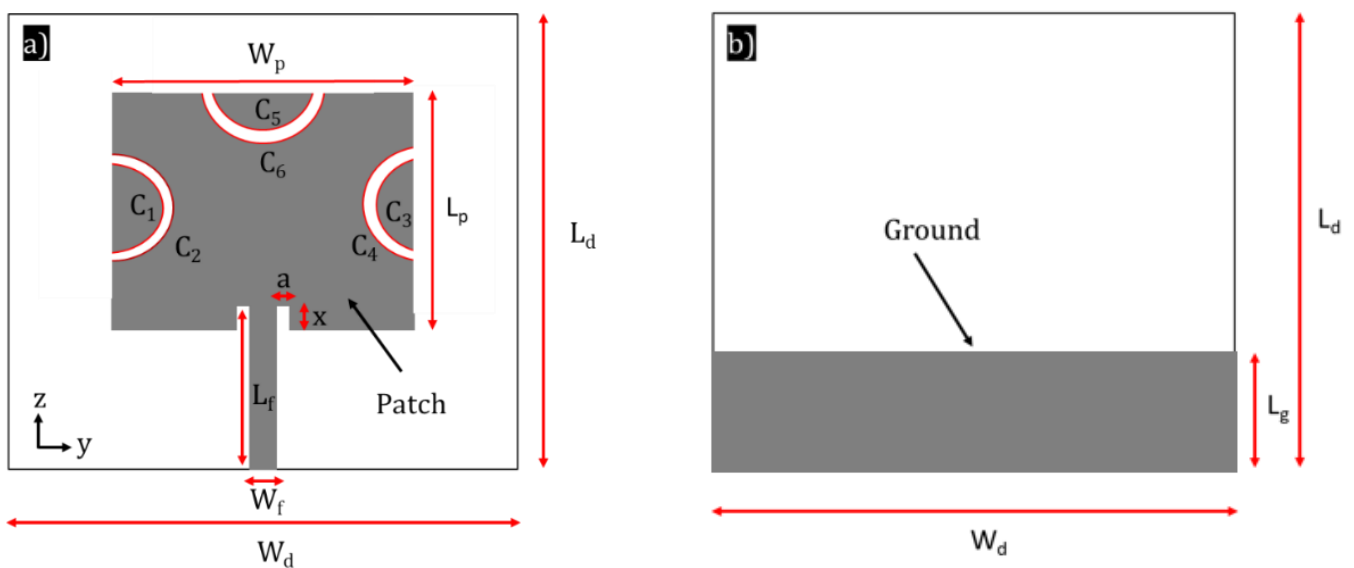

Figure 1. The structure of the proposed antenna, a) front view, b) rear view.

The dimensions of the proposed microstrip patch antenna is given in Table 2 .

Table 2. Dimensions of the proposed antenna.

\begin{tabular}{|c|c|c|c|c|c|c|}
\hline Parameter & $\mathbf{W}_{\mathbf{d}}=\mathbf{L}_{\mathbf{d}}$ & $\mathbf{W}_{\mathbf{p}}$ & $\mathbf{L}_{\mathbf{g}}$ & $\mathbf{W}_{\mathbf{f}}$ & $\mathbf{C}_{\mathbf{2}}=\mathbf{C}_{\mathbf{4}}$ & $\mathbf{C}_{\mathbf{1}}=\mathbf{C}_{\mathbf{3}}$ \\
\hline $\begin{array}{c}\text { Value } \\
(\mathrm{mm})\end{array}$ & 60 & 28 & 15 & 3 & 19.98 & 13.69 \\
\hline Parameter & $\mathbf{L}_{\mathbf{f}}$ & $\mathbf{a}$ & $\mathbf{x}$ & $\mathbf{L}_{\mathbf{p}}$ & $\mathbf{C}_{\mathbf{5}}$ & $\mathbf{C}_{\mathbf{6}}$ \\
\hline $\begin{array}{c}\text { Value } \\
(\mathrm{mm})\end{array}$ & 21.86 & 1.5 & 4.36 & 25 & 11.59 & 17.93 \\
\hline
\end{tabular}

The antenna is built on a low-cost substrate $60 \mathrm{~mm}$ long and $60 \mathrm{~mm}$ wide. The structure is fabricated using the LPKF (S63) PCB prototyping machine on a low-cost FR4 substrate (loss tangent $=0.02$ ) with 1.6 mm thickness and 4.3 relative permittivity. Fabricated antenna is shown in Figure 2.

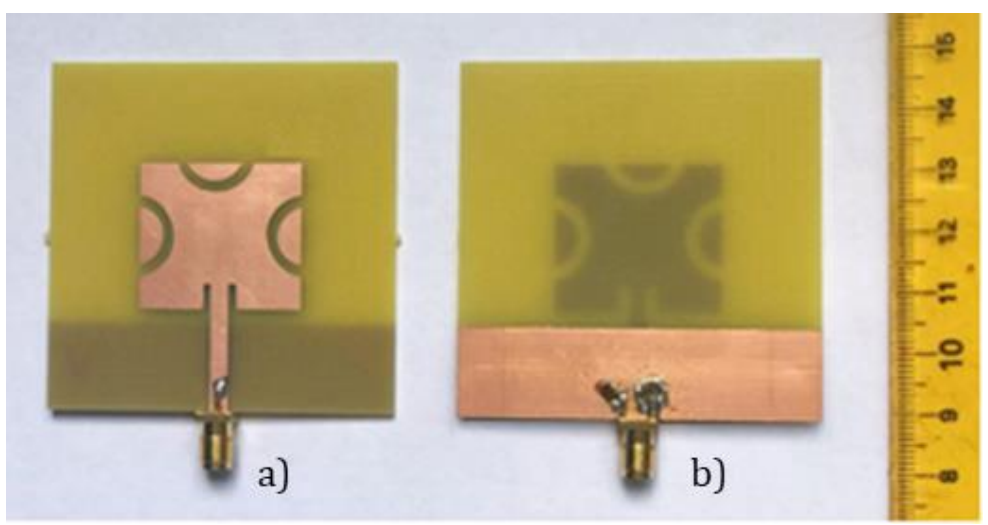

Figure 2. Fabricated antenna a) front view, b) rear view. 
In Figure 3, the S-parameter (S11) versus frequency curve for the proposed antenna design is presented. Simulations are carried out by CST Microwave Studio. To validate to results, the fabricated antenna is measured using the Rohde\&Schwarz vector network analyzer (VNA) with model no.ZVA40. According to the results in Figure 3 , operating frequency range of the microstrip patch antenna with slots added rectangular is almost from 2.267 GHz to $3.587 \mathrm{GHz}$.

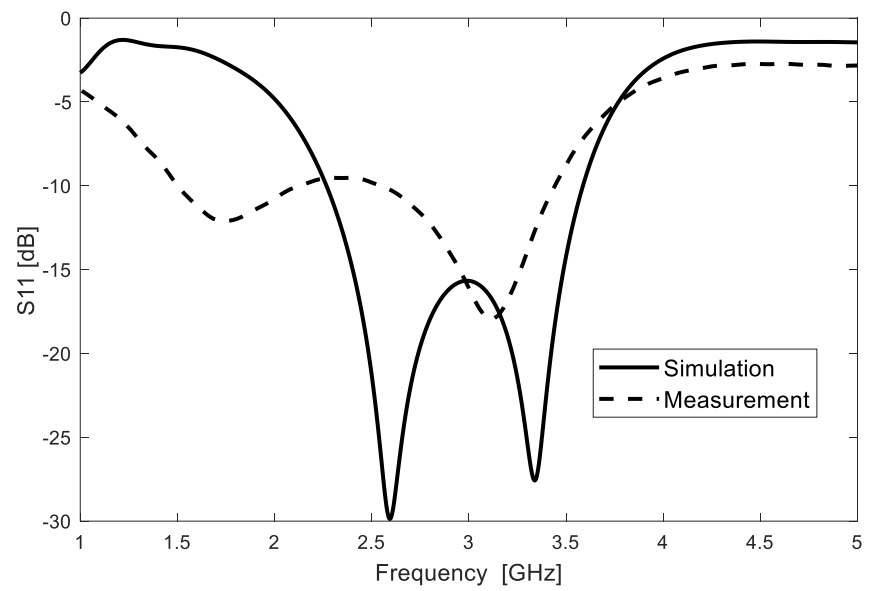

Figure 3. The simulation and measurement results for reflection coefficients of the proposed microstrip patch antenna.

\section{Experimental Results}

Figure 4 shows the gain $(\mathrm{dB})$ of the proposed microstrip patch antenna. The antenna's gain has the tendency to increase with the increase in frequency within the UHF RFID band. From the figure it is noticed that the gain of antenna varies between 2.065 to $2.24 \mathrm{~dB}$ within the operating frequency band and with the maximum gain of 2.24 $\mathrm{dB}$ at $3.0736 \mathrm{GHz}$. The lowest gain is found at the $2.26 \mathrm{GHz}$ frequency with a $2.065 \mathrm{~dB}$. Designed antenna gain at resonance frequencies are $2.169 \mathrm{~dB}$ at $2.592 \mathrm{GHz}$ and $2.175 \mathrm{~dB}$ at $3.338 \mathrm{GHz}$.

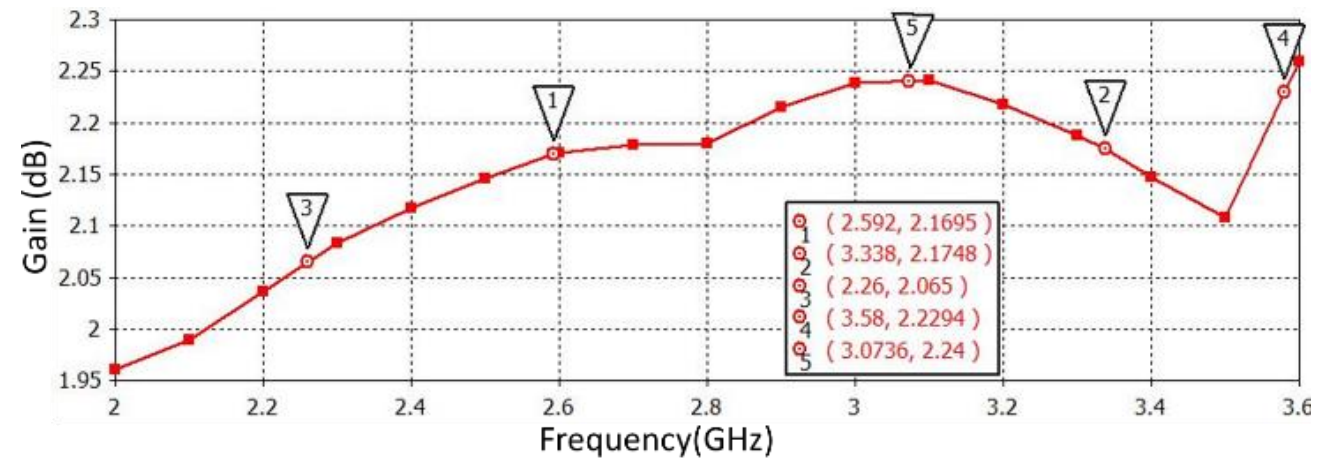

Figure 4. Gain ( $d B)$ versus frequency.

The 3D gain of the designed antenna is presented in Figure 5 a) at $2.592 \mathrm{GHz}$ and b) $3.338 \mathrm{GHz}$. Designed microstrip patch antenna provides a maximum directive gain about $2.169 \mathrm{~dB}$ at $2.592 \mathrm{GHz}$ and $2.175 \mathrm{~dB}$ at $3.338 \mathrm{GHz}$. Both resonance frequencies have nearly same gain values.

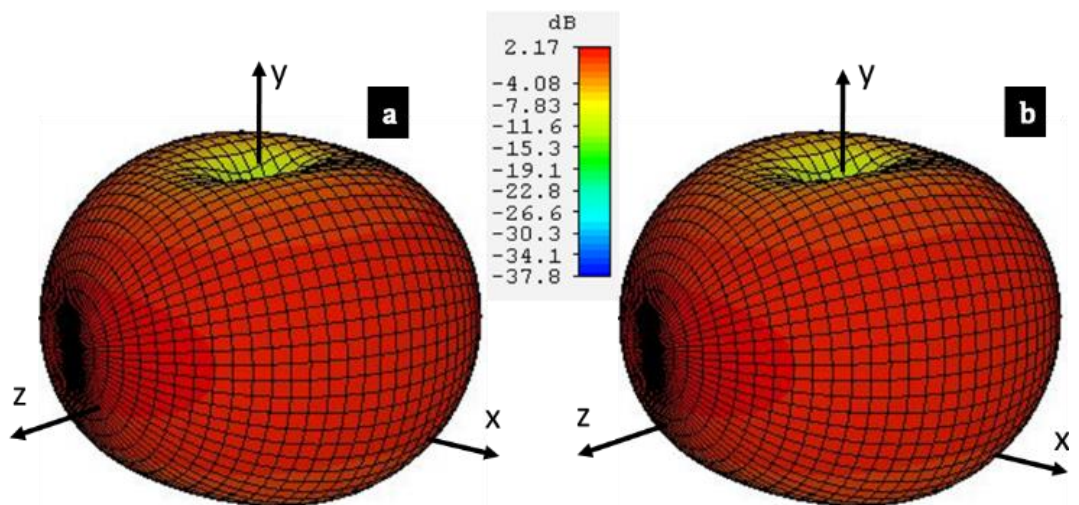

Figure 5. 3D Gain plot of the proposed antenna at a) at $2.592 \mathrm{GHz}$ and b) at $3.338 \mathrm{GHz}$. 
The simulated radiation pattern graphs of the proposed antenna are shown in Figure 6.
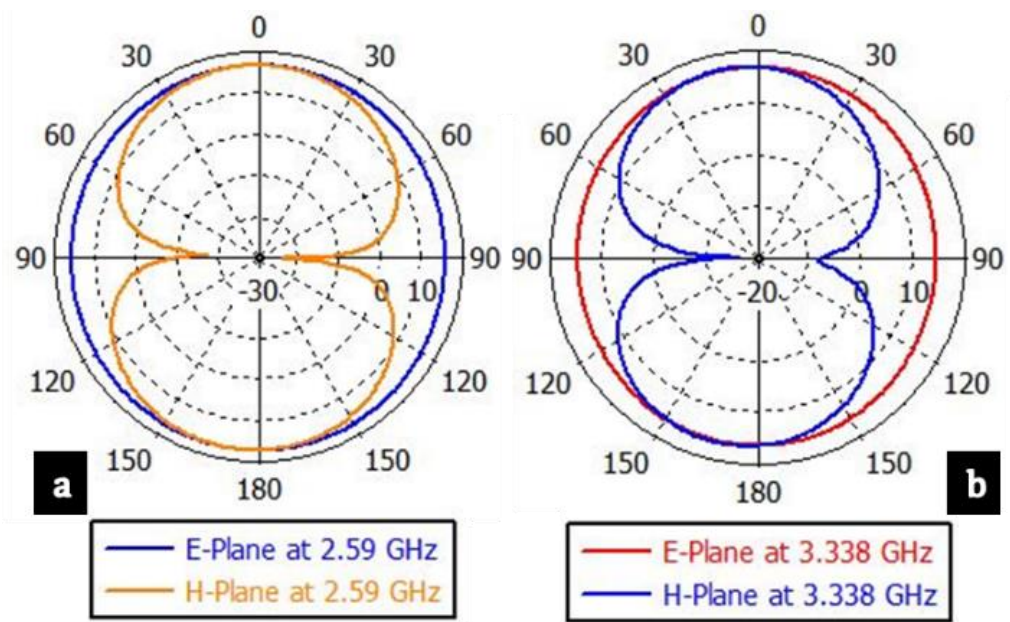

Figure 6. Simulated radiation patterns in the $\mathrm{E}$ and $\mathrm{H}$ planes for the proposed antenna (a) at $2.59 \mathrm{GHz}$ and (b)at $3.338 \mathrm{GHz}$

Figure 7 shows the simulated current distribution in circular slotted microstrip patch antenna at $2.592 \mathrm{GHz}$ and $3.338 \mathrm{GHz}$ resonance frequencies. The current distribution is dense and well spread. Efficiency of the antenna depends on the current distribution. Designed circular slotted microstrip patch antenna surface current amplitude is $150 \mu \mathrm{A} / \mathrm{m}$ at $2.592 \mathrm{GHz}$ and $151 \mu \mathrm{A} / \mathrm{m}$ at $3.338 \mathrm{GHz}$.

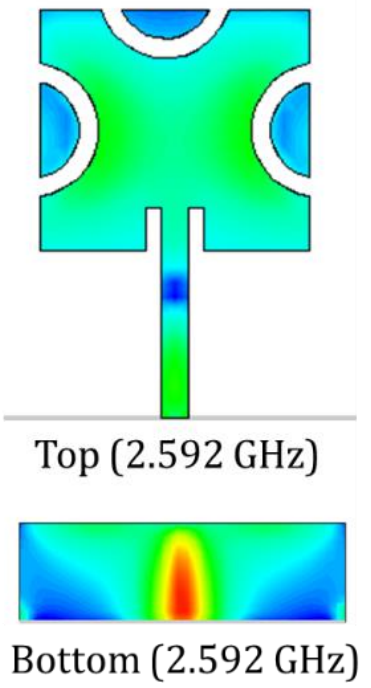

a)

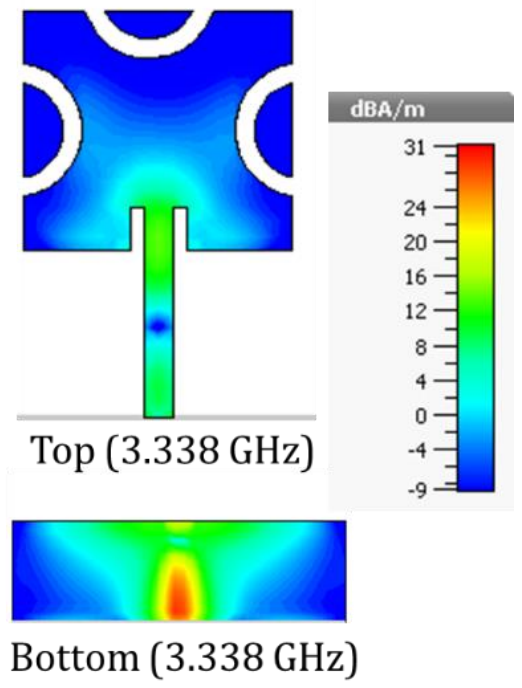

b)

Figure 7. Surface currents of the proposed antenna a) for $2.592 \mathrm{GHz}$, b) for $3.338 \mathrm{GHz}$.

\section{Results and Discussion}

Microstrip antenna has become one of the most preferred antenna types in communication systems as it has small size, easy adaptation to electronic circuits, low cost and operating at multiple frequencies. In this study, a new antenna design has been proposed to meet the need for microstrip patch antenna designs such as broa dBand and multiple resonance frequencies arising from the reasons such as increasing the data transfer rate and the continuous data transfer WLAN/WiMAX band applications which are widely used in wireless communication systems. The designed antenna is a modified form of the rectangular patch antenna consisting of three identical circular slots in the patch surface. Proposed antenna has two different operating frequencies, with center frequencies of 2.592 and $3.338 \mathrm{GHz}$ and by modifying antenna with slots, bandwidth of the antenna is improved by $50.9 \%$ and $39.5 \%$ at these resonance frequencies, respectively. The numerical analysis of the proposed antenna such as reflection coefficients (S11 parameters), directive gain, surface current and radiation patterns examined by using CST Microwave Studio. Return loss of the proposed antenna is $-29.87 \mathrm{~dB}$ at $2.592 \mathrm{GHz}$ and $-27.57 \mathrm{~dB}$ at $3.338 \mathrm{GHz}$ and $10 \mathrm{~dB}$ bandwidth is $1.32 \mathrm{GHz}$. Gain values are varying between $2.06 \mathrm{~dB}$ and $2.24 \mathrm{~dB}$ within the operating band. The proposed antenna has proven to be able to achieve high performance and is suitable for 
wireless communication systems.

\section{Conflict of Interest}

No conflict of interest was declared by the authors.

\section{References}

Gupta, A. K., Kumar, N., 2015. Dual band meander slot antenna for mobile applications. 2015 International Conference on Communications and Signal Processing (ICCSP), 828-830.

Yassin, A. A., Saeed, R. A., 2013. Reconfigurable Dual Band Antenna for 2.4 and $3.5 \mathrm{GHz}$ using Single PIN Diode. 2013 International Conference On Computing, Electrical And Electronic Engineering (ICCEEE), 63-66.

Armağan, O., Kahriman, M., 2016. 2.45 GHz, 3.7 GHz ve 5.8 GHz frekanslarda çalışan üç-bant yama anten tasarımı. Mühendislik Bilimleri ve Tasarım Dergisi, 4 (3), 189-193.

Ding, Y., Zang, H. Z., Liu, W. L., Yang, B., 2012. Dual-band miniaturized printed antenna for WLAN applications. IEEE International Conference on Microwave and Millimeter Wave Technology (lCMMT), 3, 1 -4.

Değirmenci E., Akman H., Kahriman M., 2014. ISM 1800 MHz ve 2450 MHz Frekanslarda Kullanılabilecek Daire ve Dikdörtgen Yarıklı Dual Band Anten Tasarımı. IEEE 22. Sinyal İşleme ve İletişim Uygulamaları Kurultayı. 23-25. Karadeniz Teknik Üniversitesi, Trabzon.

Gemio, J., Junkin, G., Parron, J., and Villarino, R., 2009. Resonator-loaded dual-band monopole for universal WLAN. IEEE Antennas Wireless Propag Lett., 8, 736-739.

Kumari R., Behera S. K., 2012. A compact dual resonance dielectric resonator antenna array with partial ground plane. Proceedings of 1st international conference on recent advances in information technology (RAIT 2012). 809-812.

Sharma, R., Kumar, M., 2012. Dual band microstrip- fed printed antennas for wireless applications. Fourth International Conference on Computational Intelligence and Communication Networks, 37 - 40.

Rosaline, S. I., Raghayan, S., 2015. Compact dual band antenna for GSM/WiMAX applications. 3rd International Conference on Signal Processing, Communication and Networking (ICSCN). 1-3.

Ismail, S., Rahim, S., Ibrahim, A., Sabran, M., Mohamad, H., 2015. Dual band inverted H-shaped slot monopole antenna for WLAN applications. 2015 IEEE 12th Malaysia International Conference on Communications (MICC). 197-200.

Liu, S., Wu, W., Fang, D. G., 2016. Single-feed Dual-layer Dual-and Eshaped and U-slot Patch Antenna for Wireless Communication Application. IEEE Antennas Wireless Propag. Lett., 15, 468- 471.

Wu, Y. T., Chu, Q. X., Yao, S. J., 2013. A dual-band printed slot diversity antenna for wireless communication terminals. 2013 IEEE International Wireless Symposium. 1-3. 